ECONOMICS

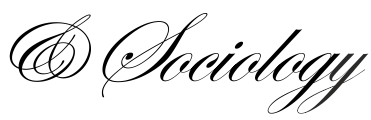

Lubian, D. (2020). Are virtuous people happier? Evidence from Italy. Economics and Sociology, 13(1), 146-164. doi:10.14254/2071-789X.2020/13-1/10

\title{
ARE VIRTUOUS PEOPLE HAPPIER? EVIDENCE FROM ITALY
}

\author{
Diego Lubian \\ University of Verona, \\ Verona, Italy \\ E-mail:_diego.lubian@,univr.it
}

Received: September, 2019

1st Revision: December, 2019

Accepted: February, 2020

DOI: $10.14254 / 2071-$

789X.2020/13-1/10

\author{
JEL Classification: D91, \\ C21, A13
}

\begin{abstract}
The strength of norms of civic cooperation are known to be important for measurable macroeconomic outcomes, such us GNP and investment growth. At the individual level, lack of civic virtue or selfishness in interpersonal relationships is often found to be negatively correlated with happiness. In this paper we provide new empirical evidence on the relationship between happiness and civic virtue using data from the Survey of Italian Households' Income and Wealth. Besides regression results confirming the positive correlation between civic behavior and happiness, we provide novel empirical evidence of a positive correlation between happiness and selfish/asocial behavior. Our findings indicate that people with extreme views, either in the civic direction or in the selfish one, are happier than the others. In addition, the two effects are of a different order of magnitude and we find that the effect on happiness of having a selfish attitude is greater than the pro-social one.
\end{abstract}

Keywords: happiness, civic virtue, prosocial behavior

\section{Introduction}

How happiness and economic behavior are related is a topic of interest in many fields of the social sciences, in particular in economics and psychology. Under the neoclassical approach to economic choices, individuals choose the optimal bundle of goods and services according to their preferences so as to maximize utility. The underlying assumption is that only the individual knows what is best for her/him (Mill, 1991) and, as a consequence, her/his maximizing behavior will produce the overall best result for the society. Psychologists have often used the concept of "subjective wellbeing" to measure, in a much general sense, how individuals feel about their lives, beyond the utility associated to given choices generated by individuals' preferences (Diener et el., 1999). Considering both decision utility and experienced utility behavioral economics attempts to provide a bridge between economic theory and psychological and sociological explanations of the observed behavior of individuals in the economic environment.

The aim of this paper is to investigate the relationship between happiness and civic virtue, broadly defined as the relation between the individual and the community as a whole. A virtuous individual will act in a morally right way by foregoing private interests for public ones to the benefit of the whole community. Conversely, a selfish behavior places one's wellbeing above and beyond that of other fellow citizens. Social dilemmas in which a conflict arises between self-interest and collective interest are pervasive in economics (see, for instance, Cubitt 
et al., 2011). The classical example is the provision of a public good from which the whole community would benefit but for which an individual contribution is required giving rise to a private incentive to free ride. Generosity in charitable givings, self-reported tax evasion, contributions in dictator games, volunteering, environmentally friendly behavior are additional examples of economic settings in which a dilemma between civic and selfish behavior may arise. The research question of interest is: does civic behavior lead to happiness?

The empirical evidence on the correlation between happiness and civic virtue is mostly, but not univocally, in favor of a negative correlation with happiness decreasing with selfishness, see Lane (2017) for a recent review. In this paper we shall analyze this issue by using individual survey data on Italian households taken from the Survey of Italian Households' Income and Wealth. This dataset is well suited for this investigation since contains specific questions on civic behavior that allow us to study the civic attitude both in the interpersonal relationships and towards the community. From a methodological point of view, differently from previous studies we consider separately the extreme attitudes, i.e., the pure selfish and the pure civic behavior. Using ordered Probit models to model the ordered responses on the level of happiness we provide novel and robust empirical evidence that the most intense attitudes, i.e., pure selfish and pure prosocial ones, are positively correlated with happiness suggesting that extreme views, in one direction or the other, are positively associated to happiness. Our results parallel recent findings by Curini et al. (2014) and Jackson (2019) in the political science literature who find a U-shaped relationship between happiness and political views so that individuals with more radical opinions are significantly happier than the others.

The plan of the paper is as follows: in the next section we briefly review the literature on the happiness and economic outcomes and behavior, next we describe the dataset and discuss the methodology used in the empirical investigation. Then, we present the main findings of the analysis. Some concluding remarks are left to the last section.

\section{Literature review}

Measures of subjective wellbeing from survey data have been extensively used by economists to relate happiness to economic outcomes and economic behavior. According to the famous Easterlin's paradox (Easterlin, 1973, 1974) subjective wellbeing is positively correlated with income in a given year even though the correlation disappears both across countries and in the time series dimension. An important factor is given by relative income, richer people are happier than the others but average subjective wellbeing stays roughly constant as all individuals become richer (Easterlin, 1995). In a seminal paper Di Tella et al. (2003) show how subjective wellbeing is also affected by the general state of the economy. Considering the relationships between happiness and economic performance for the US and several European countries they provide empirical evidence that happiness increases monotonically with income while it decreases with inflation.

Individual determinants of happiness/subjective wellbeing are usually sought in the work domain, in the family domain and in personality traits. Clark et al. (2018) provide a recent review of the empirical findings on the determinants of life satisfaction starting from the foundations of happiness in childhood (related to family characteristics such as parents income, family stability, parenting childcare, school experience) and then moving to examine adult outcomes (individual income, employment, marital status and health).

There also exists a huge literature on the demographic and socio-economic determinants of subjective wellbeing (see, for instance, Dolan et al., 2008; MacKerron, 2012, for reviews). Among the established determinants of subjective wellbeing we have individual income and individual characteristics such as age, health, ethnicity, gender, education, the working status and conditions. A U-shaped pattern characterizes the age-happiness relationship suggesting that 
younger and older people are happier, however recent empirical evidence indicates that social context effects may significantly flatten this U-shape pattern (Helliwell et al., 2019). The sign and magnitude of a gender effect on happiness is unclear, happiness appears to be declining over time for women giving rise to the so-called gender paradox in happiness (Stevenson and Wolfers, 2009). Similarly, black and white differences in the level of happiness are declining over time with income and marital status accounting for much of these differences where, interestingly, the predictive power of these factors has increased over time (Iceland and Ludwig-Dehm, 2019). The evidence on the effect of education on happiness is mixed, Shields et al. (2009) find a negative effect while Oreopoulos and Salvanes (2011) find a positive one, and Veenhoven (2010) concludes that education is probably the only capability that does not affect happiness.

From a different perspective, a complementary strand of literature is concerned with how happiness is related both to individual preferences in specific economic domains and to interpersonal economic behavior (see Lane, 2017, for a comprehensive review). The sign and strength of the correlation between happiness and risk preferences is unclear. On the one hand, some studies have found some positive correlation (Kahyaoglu \& Ican, 2017; Delis \& Mylonidis, 2015) while, on the other hand, some other studies find a negative correlation (Delis \& Mylonidis, 2015). Similar remarks apply to the effect of happiness on risk-taking behavior, both in economic and non-economic settings, with some evidence supporting the view that a positive mood would promote a risk-taking behavior (as in the Affect Infusion Model, see Forgas, 1995) while other studies favor the view that positive mood would entail a more riskaverse behavior (as in the Mood Maintenance Hypothesis, see Isen and Patrick, 1983). Overall, the evidence is not conclusive and the size of the correlation, if any, between happiness and risk-taking behavior is found to be rather small or negligible (see, for instance, Campos andVazquez \& Cuilty, 2014; Hu et al., 2015; Yechiam et al., 2016). Similar remarks apply to the correlation between happiness and time preferences, even though the empirical evidence is limited. For instance, Ifcher and Zarghamee (2011) find that subjects exposed to a positive affect treatment reduce time preference while Drichoutis and Nayga (2013) find that both positive and negative mood states increase patience (see Lane, 2017, for a review).

Looking now at the attitudes and beliefs towards the others, a special role is played by the relation between happiness and social capital. The set of beliefs, values and rules of behavior embodied in trust are key elements at the root of any kind of interpersonal relationship and they can significantly affect actions taken by individuals in economic and financial issues. Social capital has been found to influence positively individual happiness both across countries and time (Helliwell, 2006; Bartolini et al., 2016).

The empirical evidence on the correlation between happiness and selfish behavior is mostly but not exclusively in favor of a negative correlation. Considering both experimental studies and survey data, volunteering and generosity exert a positive effect on well-being both in the short run and in the long run. Experiment designed to measure the subjective wellbeing of individuals who had the opportunity or were forced to choose between spending money for themselves or generously indicate that people spending money generously experience higher subjective wellbeing than the others (Dunn et al., 2008). Similar findings have been obtained from dictator games where selfish players have a mood deficit with respect to generous ones (however, notice that Bischoff and Krauskopf, 2015, find that the positive association between happiness and generosity holds when the decision is made on his/her own rather than in a group).

Using data from the World Value Survey, some studies have considered in detail the relationship between happiness and ethical behavior (James, 2011) or civic virtue (Stavrova et al., 2013) considering the beliefs or stated (not actual) behavior in some hypothetical scenario. Both studies consider WVS surveys in which individuals are asked the degree in which they 
justify claiming government benefits to which they are not entitled, avoiding a fare on public transport, cheating on taxes if they have a chance and accepting a bribe in the course of his/her duties.

James (2011) considers data from wave 5 of the World Value Survey (2005-2006) focussing on four countries in the Americas, he finds that ethical behavior has a positive effect on happiness but that the size of the effect is country-specific suggesting that cultural factors may be relevant in how ethical behavior translates in higher happiness. Stavrova et al. (2013) investigate whether the correlation between happiness and civic virtue is mediated by the country's antisocial punishment and the country's mean civic virtue. Combining the 2011 wave of the European Value Survey and the data from the World Value Survey carried out in the period 2005-2008 (103,200 individuals in 73 countries), they provide convincing evidence that there exists a positive correlation between civic virtue and happiness and that its magnitude is related to the country's normative climate, i.e., the correlation between civic virtue and happiness is greater in countries where the mean level of justification of unethical behavior is lower.

\section{Methodological approach}

\subsection{Data}

The empirical analysis uses individual data from the 2004 wave of the Survey of Italian Households' Income and Wealth (SHIW) run by the Bank of Italy. The survey provides data on social, demographics and economic characteristics of about 8,000 households for a total of 20,581 individuals (available here: http://www.bancaditalia.it/statistiche/tematiche/indaginifamiglie-imprese/bilanci-famiglie/index.html). In particular, the dataset contains individual data on gender, age, civil status, households' composition, employment, educational level as well as detailed information on income and wealth (both financial wealth and real assets). Further, this specific wave of SHIW contains the happiness question (with answers on a 1-10 scale) and several questions on the civic attitude.

The final dataset consists of 3,798 observations. Some descriptive statistics on the demographic and economic characteristics of the sample used in the analysis are reported in Table 1. As for the demographic profile of the sample, the average age is 57, slightly less than $40 \%$ of the household heads are females, overall only $9 \%$ of household heads have been awarded a B.A. degree ("Laurea") and an additional 30\% have a high school diploma. Households with 2 or more components are about $75 \%$ of the sample, only one income earners is present in $46.8 \%$ of the households and in an additional $40 \%$ of the households we observe two income earners. Only about $10 \%$ of household heads are self-employed and $45 \%$ are retired. Our measure of income is given by net disposable income with an average of 30,400Euro (median income is 24,600Euro). Financial wealth is defined as the sum of cash holdings, bank deposits (including certificates of deposit, deposit books and saving certificates), government securities, mutual funds holdings, shares of stocks, life insurance premium and pension funds. Real assets are obtained as the sum of real estate, precious objects and business equity minus financial liabilities. Average financial wealth is about 26,000Euro (median equal to 9,500Euro) and average real assets is about 193,000Euro (and about $80 \%$ of the households are homeowner). 


\subsection{Measurement}

This wave of SHIW contains both the happiness question (with answers on a 1-10 Likert scale) and several questions on the civic attitude. In particular, the section labeled "Opinions on public spirit and taxation", answered by household heads born in odd years only, is specific to the 2004 wave (it is not present in other waves) so that it provides a unique opportunity to study the relationship between happiness and virtue. Further, it allows for a rich set of sociodemographic and economic control variables, which are often not available in the other survey data on happiness or subjective well-being such as, for example, the WVS.

The question on the civic attitude explore both the dimension of the pure free-riding behavior in the provision of a public good and the individual's intrinsic honesty when having of the possibility of keeping other people's money or avoiding paying damages to third parties.

Civic virtue. Which of the following situations do you think are always justifiable, never justifiable, or justifiable to some extent? Please provide your answer on a scale from 1 to 10,1 being 'never justifiable', 10 being 'always justifiable' and the numbers in between indicating various degrees of response.

a) Not paying for your ticket on public transport.

b) Keeping money you obtained by accident when it would be possible to return it to the rightful owner (for example, if you found a wallet with the owner's name and address, or if you were given too much change at the supermarket check-out).

c) Not leaving your name for the owner of a car you accidentally scraped while parking.

Part (a) is analogous to a question posed in each wave of the WVS (2014) and it has been analyzed by, among others, Stavrova et al. (2013). Avoiding paying the fare on a public transport is a textbook example of free-riding behavior. Each individual has a selfish incentive not to pay the ticket relying on the contribution of the others to finance the public good. Part (b) and (c) are not available in the WVS and are specific to this wave of SHIW. They are clearly related to the individual's civic virtue but with a different nuance with respect to (a). In fact, while part (a) refers to a free riding behavior with direct reference to a public good, part (b) and (c) are related to the attitude towards specific individuals who are explicitly identified in (b) or could easily be in part (c). Overall, the answers to the three items are helpful to shed light on the civic virtue of the respondent.

The survey also contains a standard question on happiness:

Happiness. Looking at every aspect of your life, how happy would you say you are? Please answer on a scale of 1 to 10 , where 1 is "Very unhappy", 10 is "Very happy" and the figures in between indicate various degrees of response.

The histogram of the answers to the happiness question is displayed in Figure 1, average happiness is 6.84 with a standard deviation of 1.82 . 


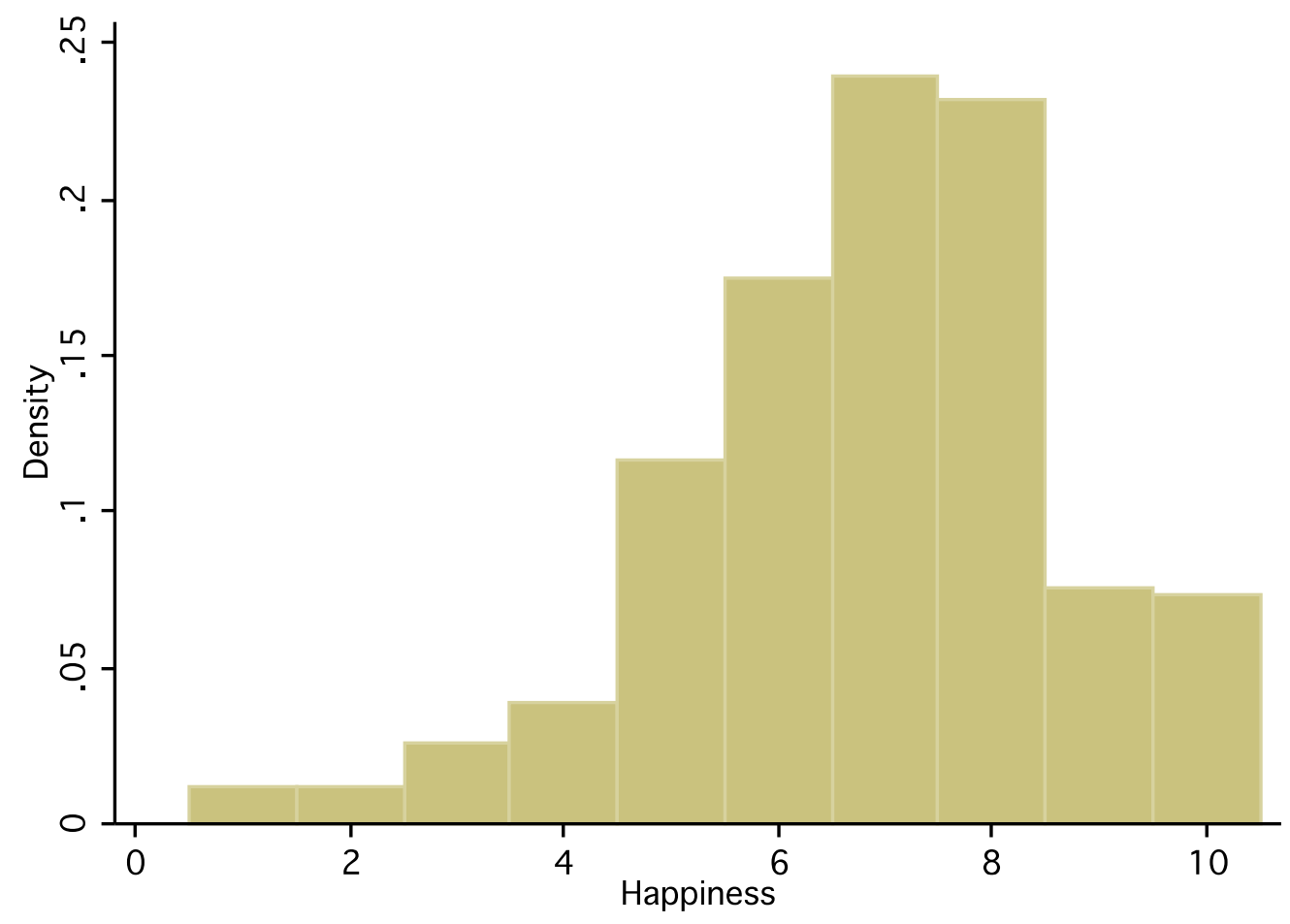

Figure 1. Distribution of happiness

Source: SHIW 2004

\subsection{Econometric method}

We explicitly take into account the ordinal nature of the answers to the questions on civicness and happiness by estimating ordered Probit models. We decided for this methodological approach because it allows us to fully preserve the ordering of the responses and it does not assume a constant fixed interval between the answers as it would have been if estimating a linear model by OLS. Briefly, this amount to assume that the underlying continuous latent dependent variable, say $y_{i}^{*}$, is linearly related to a set of regressors, say $\boldsymbol{x}_{i}$, as follows

$$
y_{i}^{*}=x_{i}^{\prime} \beta+u, \quad u \mid x \sim N(0,1)
$$

where $\beta$ is a vector of parameters and $u$ is the error term. The response mechanism is such that we observe $y=j$ whenever $c_{j-1} \leq y_{i}^{*}=x_{i}^{\prime} \beta+u \leq c_{j}$ for $j=1, \ldots, J$, where the $c$ 's represent a set of cut-off points discretizing the continuous latent variable $y^{*}$, into $J$ observed ordered categories. Therefore, in our settings we assume that subjective wellbeing is a latent variable, observed in discrete values in the scale 1-10, and that the regressors include the attitude towards civic virtue, which is the main regressor of interest, and socio-demographic variables as controls.

The vector of coefficients $\beta$ as well as the cut-off points $c$ 's are estimated by Maximum Likelihood. The estimated coefficients from ordered Probit models can be interpreted as follows: a positive coefficient implies that an increase in the (associated) regressor determines an increase in the latent variable which, in turn, will always determine an increase in the probability of the highest category and a decrease in the probability of the lowest category, while the direction of the effect on all intermediate categories cannot be determined uniquely. Therefore, simple inspection of the coefficients helps to assess the direction of the effect on the dependent variable, which will be civic behavior or happiness in the empirical analysis, only 
for the two extreme outcomes 1 and 10. A detailed representation of the effect of each regressor on the ordinal dependent variable can be obtained by looking at the average marginal effects. A convenient way of reporting the marginal effects of interest makes use of graphical methods. For instance, this can be accomplished with a graph where on the horizontal axis we have the ordered categories for the dependent variable and on the vertical axis we read the effect of a change in the regressor of interest (i.e., attitude towards civic virtue) on the probability of each outcome. The effect on happiness of radical opinions on "civic" issues will be discussed in the next subsection by looking first at the estimated coefficients and then making use of graphical methods.

\section{Conducting research and results}

In this section we provide empirical evidence on whether virtuous and/or asocial people are happier. We start by investigating the determinants of civic virtue and then we proceed to the main object of interest, the relationship between happiness and civic virtue.

\subsection{Determinants of civic virtue}

Table 2 reports the estimated coefficients for ordered Probit models where the dependent variable is, respectively, the categorical answer to part (a), (b) and (c) of the civic virtue question, say "Ticket", "Wallet" and "Car", and the regressors are given by the demographic and socio-economic characteristics of the household head such as age, gender, civil status, education, employment status, household size and earners, regional and urban dummies, income, financial and real wealth. We can interpret the sign and the statistical significance of the estimated coefficients from ordered Probit model for civic behavior as follows: a positive coefficient implies that an increase in the (associated) regressor decreases the probability of the lowest category, i.e., the pure selfish attitude, and increases the probability of the highest category, i.e., the most prosocial attitude. Nothing can be said on the probabilities associated to the intermediate categories by simple inspection of the estimated coefficients.

Among the main determinants of the attitude towards civic matters we find the educational level. In fact, the coefficients on the High School and College dummies have a negative sign and are significant at the $5 \%$ or $1 \%$ level. The negative coefficients associated to education imply that as the individual obtains higher levels of education the probability that she/he finds the behavior "never" justifiable increases and, at the same time, the probability that she/he finds the behavior "always" justifiable decreases. Thus, higher educational levels are positively correlated with civic virtue. This finding suggests that education not only provides private (higher wages) and social returns (skilled labor force) but also might promote greater civicness. Geographical and urban factors such as the macro-area of residence and the size of the town are also statistically significant. Living in a medium size or big town increases the probability of a lower degree of civicness with respect to a small town, as does living in Central or Southern Italy with respect to Northern Italy. These findings provide support to the view that living in smaller towns might promote a greater sense of community, a greater civicness that might dampen free riding behavior. As argued by Olson (1965), small groups are qualitatively different from large ones and free riding is more likely to emerge in the latter than in the former environments. Further, macro-regional differences across Italy may be explained in terms of the well-known low level of the stock of social capital in Southern Italy, see for instance Putnam (1993), and in line with Banfield (1958)'s findings of lack of trust outside the family circle (the so-called "amoral familism"). Finally, homeownership and higher financial wealth are positively correlated with civic virtue. Most of these results are not surprising, in particular, the 
sign of the correlation between civic virtue and educational levels, geographical and urban factors.

\subsection{Happiness, civic virtue and selfishness}

We now turn to the analysis of the relationship between happiness and civic virtue. Table 3 reports the estimated coefficients obtained in Ordered Probit models where the dependent variable is "Happiness" (score 1-10).

In the first column we have estimation results using the usual covariates considered in the literature to study the determinants of happiness. The negative coefficient on age and the positive coefficients on age squared indicate that an increase in age has a negative effect on the share of very unhappy and very happy people, but at a diminishing rate. An increase in the educational level and marriage have a positive effect on both the lowest and highest level of happiness while unemployment has a negative effect. Similarly, living in Central and Southern Italy has a negative significant effect while, not surprisingly, wealth has a positive effect on the highest and lowest level of happiness. These results are largely in line with those found in the empirical literature on the correlation between happiness and socio-demographic and economic variables (see the survey in Dolan et al., 2008).

Then, we focus in column (2)-(4) where, in turn, we add a dummy explanatory variable equal to 1 if the respondent believes that it is "never" justifiable (a) not paying for the ticket on public transport, namely "Ticket (never)", (b) keeping money obtained by accident when it would be possible to return it to the rightful owner, namely "Wallet (never)", and (c) not leaving the name for the owner of a car accidentally scraped while parking, namely "Car (never)". Thus, these three dummy variables isolate very determined prosocial behavior. The estimates of the three dummies are always positive, i.e., civic behavior raises the share of individuals with the highest level of happiness and it decreases the share of individuals reporting the lower level of happiness. The effect is statistically significant at the $1 \%$ level, thus providing empirical evidence in favor of the hypothesis that civicness raises happiness.

A detailed discussion of marginal effects is postponed after Table 4. Some preliminary comments may be nevertheless worthwhile to point out the difference between estimated coefficients and marginal effects. In fact, the estimated coefficient on "Ticket (never)" is equal to $0.174(S E=0.035)$ while the marginal effect on the very happy people can be computed as 0.0234 ( $S E=0.004)$. For the regressors "Wallet (never)" and "Car (never)" we have estimated coefficients given by $0.119(S E=0.035)$ and $0.135(S E=0.036)$ and marginal effects computed as $0.016(S E=0.004)$ and $0.018(S E=0.005)$, respectively. While both the coefficients and the marginal effect on the highest outcome given by "happiness $=10$ " are statistically significant, the magnitude of the coefficients has little informative content on the magnitude of the corresponding marginal effect.

With regard to the estimated coefficients of the socio-demographic and economic controls, we notice that the magnitude, sign and statistical significance do not change in some noticeable way with respect to those in column (1). Thus, the introduction of additional regressors in columns (2)-(4) does not alter the previous findings on the determinants of happiness and it does not worsen the overall specification of the model. As for the order of magnitude of the estimated coefficients, a civic attitude has about the same effect of holding a Junior High School diploma or being a homeowner and it more than compensate the negative effect of living in a big town or in Central Italy. Overall, these results confirm previous findings in the literature (see Lane, 2017, for a review).

Is this a complete picture of the relationship between happiness and civic attitude? In Table 4 we provide further evidence on the matter by adding among the regressors a dummy variable designed to capture the most selfish and asocial behavior. To this end, for each of the 
three parts of the question on the civic virtue we define a variable equal to 1 if the respondent chooses the most selfish category by answering that the proposed action is "always" justifiable. Thus, the dummy variables associated to "never justifiable" and "always justifiable" neatly identify the more radical opinions and allows us to obtain tighter results on the association between civic behavior an subjective wellbeing. From Table 4, the estimated coefficients on the most selfish attitude are given by $0.577,0.485$ and 0.725 , respectively, indicating that selfish behavior would decrease the share of people with the lowest level of happiness and increase the share of very happy people. All coefficients are statistically significant at the $1 \%$ level and are greater than the coefficients on the dummies associated to the most civic category (never justifiable).
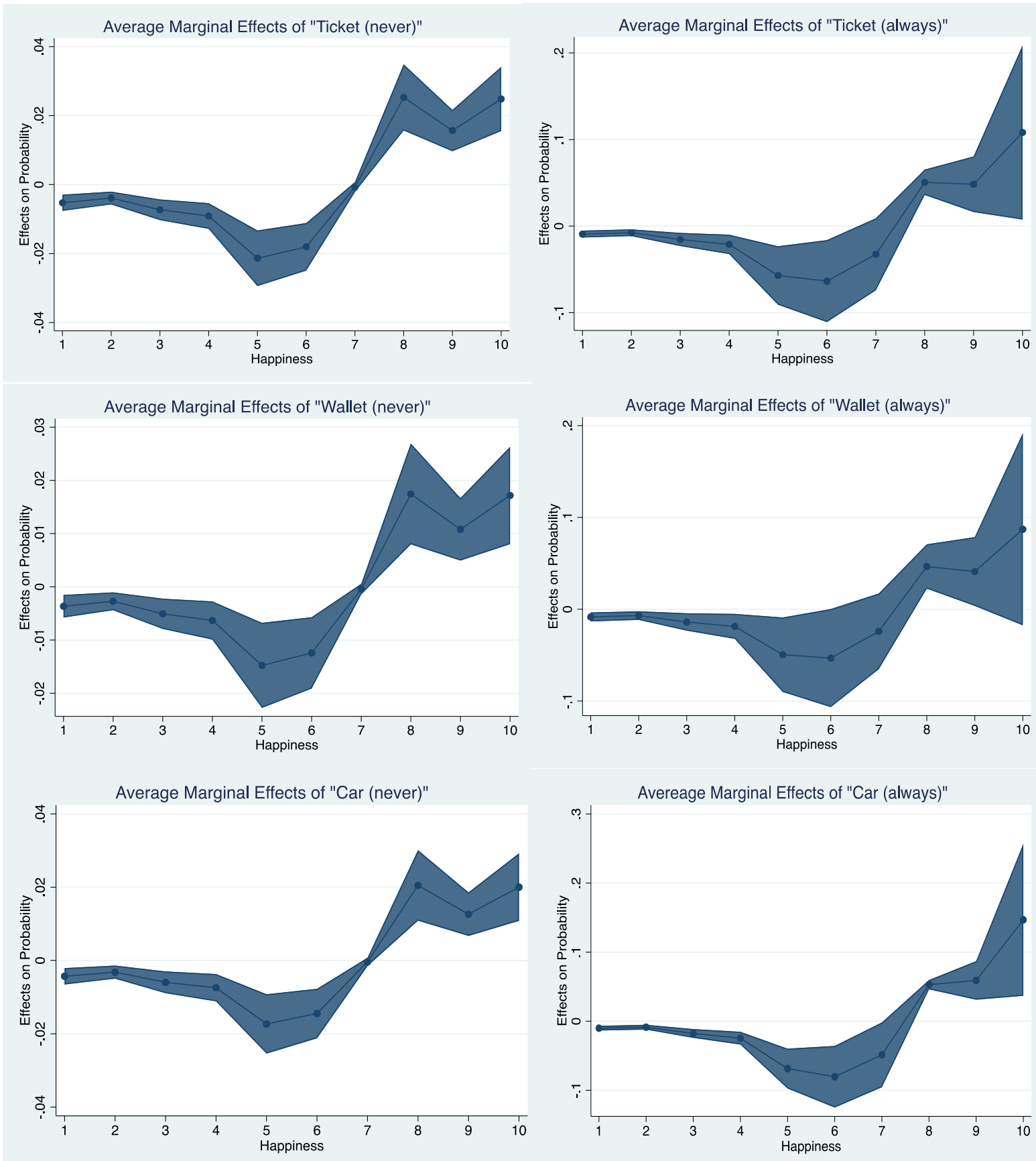

Figure 2. Average marginal effects on Happiness with $95 \%$ confidence interval Source: SHIW 2010 
A more complete assessment of the correlation between civic attitude and happiness is obtained by looking at the marginal effects on happiness of the civic and selfish dummy variables as in Figure 2. The left panels present the effect on the probability of each level of happiness following a discrete change to a virtuous attitude (never justifiable behavior) while the right panels contain the same effect after a discrete change to a selfish behavior (always justifiable behavior). First, notice that the average marginal effects share the same shape across the ten happiness categories. Secondly, following a discrete change to either a more civic or a more selfish behavior, we observe, on the one hand, an economically small, yet statistically significant, fall in the probability of experiencing lower levels of happiness and, on the other hand, an economically and statistically significant increase in the probability of observing higher levels of happiness. Further, the share of people indicating very high level of happiness increases much more than the share of very unhappy people, and this occurs when we consider shifts towards the the two extreme categories of civic behavior (left and right panels). This suggests that people with strong views, in either direction, on the issue of civic cooperation are happier than the others. This might occur for different reasons: on the one hand, people with greater "civicness" obtain higher satisfaction by following their civic and prosocial attitude (say, for pure altruism or for a warm glow effect) while, on the other hand, selfish/uncivic individuals enjoy the private benefits of truly selfish behavior. Further, it is interesting to remark that the magnitude of the marginal effects following a change to the most selfish category is much greater than that associated to the more civic one, suggesting that the effect of a selfish attitude on the share of very happy people is much larger than the effect of a civic attitude. In particular, the effect on happiness of having a selfish attitude is about three times as great than that of holding a altruistic one.

These findings that strong beliefs are positively correlated with happiness turn out to be robust to alternative definitions of selfish/unsocial behavior or aggregation of happiness. In Table 5 we report Ordered Probit estimation results considering some aggregation of the happiness scores (to save space we report the estimates of the variables of main interest, full result are available upon request). Since median happiness is equal to 7, we aggregate the scores 1-6 in the "unhappy" group, the score 7 in the "median" group and score greater than 7 in the "happy" group. The estimated coefficients on the civic dummies are very similar to those in Table 5, and the same remarks would apply, suggesting that our results are robust to different choices of grouping the happiness categories. In a second robustness check, see Table 6 , we consider as selfish those who chose categories 8,9 and 10, i.e., people who almost always find the asocial behavior justifiable. This is motivated by the fact that people might be unwilling, for shame or for social norms, to declare themselves in the extreme selfish category. Results are qualitatively similar to the previous one, the effect of the asocial behavior is to reduce the share of very unhappy people and to increase the share of very happy people. Again, the effect is greater that the effect of a shift to a civic behavior.

Finally, in Table 7 we perform an additional robustness check by considering an ordered Probit model (with 10 categories for happiness) where the explanatory dummy variables are now given by a dummy variable "civic", equal to 1 if the household answered "never justifiable" to both part (a), part (b) and part (c) of the civic virtue question, and a dummy variable "free rider" equal to 1 if the household answered "always justifiable". These individuals consistently hold the same view in the three question and, therefore, can be considered holding and expressing consistent opinions. Estimation results indicate that the coefficients on the dummies associated to the extreme views are (i) positive thereby suggesting the direct effect of decreasing the share of people with the lower level of happiness and increasing the share of people with the highest level of happiness, (ii) statistically significant at the $1 \%$ level, and (iii) the estimated coefficient on the "free rider" dummy is still greater than the coefficient on the "civic" dummy (five times as large as). 
Our results are similar to previous findings in the literature which are mostly but not exclusively in favor of a negative correlation between happiness and selfish behavior. Among others, experimental evidence in Capra (2004) and Koch (2013) support the view that there is a negative effect of selfishness on happiness, while Konow (2010) finds no association between happiness and selfish behavior. Evidence from survey data, i.e., stated behavior in hypothetical settings, report that civic individuals (free riders) are happier in countries with a low (high) level of antisocial punishment, defined as the size of the punishment inflicted by selfish individuals to altruistic ones in public good games, and that the direction of the relationship between civic virtue and happiness depends on the the extent to which prosocial behavior is rewarded in the community (Stavrova et al., 2013). Also, James (2011) finds that individuals less prone to justify unethical behavior report higher levels of subjective wellbeing which is partially in line with our results. Our results confirm that civic virtue has a positive correlation with happiness, i.e., civic people are happier. However, we also find a positive correlation between selfish behavior and happiness offering a more skeptical reading of the correlation between civic behavior and happiness. In fact, people with strong beliefs appear to be happier, irrespective of whether these views will drive an ethical or unethical behavior.

\section{Conclusion}

Does a virtuous behavior lead to happiness? Does it promote eudaimonic wellbeing? This research question has been of interest to philosophers, psychologists, sociologists and economists. The analysis carried out in this paper helps to shed light on the relationship between civic behavior and happiness by considering individual survey data on self-reported subjective wellbeing and stated civic/selfish behavior. The civic attitude has been investigated both in the interpersonal dimension (intrinsic honesty) and with respect to the community as a whole. In particular, two questions dealt with the direct interpersonal relationship between the respondent and an unknown but easily identifiable person (returning a wallet to its rightful owner and leaving a message after damaging a car), the third question is a standard one on free-riding on a fare using public transport. Interestingly, our findings that the most intense selfish and civic opinions are positively correlated with happiness are consistent across both these dimensions.

We confirm previous results in the literature on the direct association between civicness and happiness (Lane, 2017). Stavrova et al. (2013) and James (2011) provide related empirical evidence based on behavior in hypothetical scenarios where individuals were presented a conflict between their own self-interest and the that of the community they belong to (claiming government benefits to which she/he is not entitled, cheating on taxes, avoid a fare on public transport). Our analysis extends theirs in that it provides novel and robust evidence on the correlation between happiness and different unexplored facets of civic behavior. In particular, we provide additional empirical evidence in favor of the often found result that civic people exhibit higher levels of happiness. Furthermore, we provide novel empirical evidence of an effect that goes in the opposite direction, namely, selfish/asocial individuals are significantly happier than those with an average attitude towards civic virtue. Our results indicate that people with strong view, either in the civic direction or in the selfish one, are happier than the others.

These results should be interpreted with some care since they are based on survey data on a single country and not on observed behavior in actual circumstances or in laboratory experiments. However, it is noticeable that similar results have been found in the political science literature. Using data from the WVS (1980-2005 waves), Curini et al. (2014) find a Ushaped relationship between happiness and political views with individuals with more radical opinions significantly happier than the others. For the US, Jackson (2019) provides empirical evidence from survey data from GSS that individuals with extremely conservative or liberal political views are happier than those with moderate or intermediate views. Whether and the 
extent to which political orientation and stated behavior in civic virtue matters interact in determining subjective wellbeing is an interesting research question which is left for future research.

\section{Acknowledgement} apply.

I would like to thank an anonymous referee for helpful comments. The usual disclaimers

\section{References}

Banfield, E. (1925). The moral basis of a backward society. Free Press, New York.

Bartolini, S., Bilancini, E., \& Sarracino, F. (2016). Social Capital Predicts Happiness Over Time, pages 174-196. Oxford University Press.

Bischoff, I., \& Krauskopf, T. (2015). Warm glow of giving collectively-An experimental study. Journal of Economic Psychology, 51, 210-218.

Campos-Vazquez, R. M., \& Cuilty, E. (2014). The role of emotions on risk aversion: a prospect theory experiment. Journal of Behavioral and Experimental Economics, 50, 1-9.

Capra, M. C. (2004). Mood-driven behavior in strategic interactions. American Economic Review, 94(2), 367-372.

Clark, A. E., Flèche, S., Layard, R., Powdthavee, N., \& Ward, G. (2019). The origins of happiness: the science of well-being over the life course. Princeton University Press.

Cubitt, R. P., Drouvelis, M., Gächter, S., \& Kabalin, R. (2011). Moral judgments in social dilemmas: How bad is free riding?. Journal of Public Economics, 95(3-4), 253-264.

Curini, L., Jou, W., \& Memoli, V. (2014). How moderates and extremists find happiness: Ideological orientation, citizen-government proximity, and life satisfaction. International Political Science Review, 35(2), 129-152.

Delis, M. D., \& Mylonidis, N. (2015). Trust, happiness, and households' financial decisions. Journal of financial stability, 20, 82-92.

Tella, R. D., MacCulloch, R. J., \& Oswald, A. J. (2003). The macroeconomics of happiness. Review of Economics and Statistics, 85(4), 809-827.

Diener, E., Suh, E. M., Lucas, R. E., \& Smith, H. L. (1999). Subjective well-being: Three decades of progress. Psychological bulletin, 125(2), 276-302.

Dolan, P., Peasgood, T., \& White, M. (2008). Do we really know what makes us happy? A review of the economic literature on the factors associated with subjective wellbeing. Journal of economic psychology, 29(1), 94-122.

Drichoutis, A. C., \& Nayga Jr, R. M. (2013). Eliciting risk and time preferences under induced mood states. The Journal of Socio-Economics, 45, 18-27.

Dunn, E. W., Aknin, L. B., \& Norton, M. I. (2008). Spending money on others promotes happiness. Science, 319, 1687-1688.

Easterlin, R. (1973). Does money buy happiness?. The Public Interest, 30, 3-10.

Easterlin, R. (1974). Does economic growth improve the human lot? In David, A. and Reder, M., editors, Nations and Households in Economic Growth: Essays in Honour of Moses Abramovitz, pages 499-533. Academic Press, New York.

Easterlin, R. (1995). Will raising the incomes of all increase the happiness os all?. Journal of Economic Behavior and Organization, 27, 35-47.

Forgas, J. P. (1995). Mood and judgment: the affect infusion model (AIM). Psychological bulletin, 117(1), 39-66. 
Helliwell, J. F. (2006). Well-being, social capital and public policy: what's new?. The Economic Journal, 116(510), C34-C45.

Helliwell, J. F., Huang, H., Norton, M. B., and Wang, S. (2019). Happiness at Different Ages: The Social Context Matters, pages 455-481. Springer International Publishing.

Hu, Y., Wang, D., Pang, K., Xu, G., \& Guo, J. (2015). The effect of emotion and time pressure on risk decision-making. Journal of Risk Research, 18(5), 637-650.

Iceland, J., \& Ludwig-Dehm, S. (2019). Black-white differences in happiness, 19722014. Social science research, 77, 16-29.

Ifcher, J., \& Zarghamee, H. (2011). Happiness and time preference: The effect of positive affect in a random-assignment experiment. American Economic Review, 101(7), 3109-29.

Inglehart, R., Haerpfer, C., Moreno, A., Welzel, C., Kizilova, K., Diez-Medrano, J., Lagos, M., Norris, P., Ponarin, E., and et al. (eds.), B. P. (2014). World Values Survey: All Rounds - Country-Pooled Datafile Version. JD Systems Institute, Madrid.

Isen, A. M., \& Patrick, R. (1983). The effect of positive feelings on risk taking: When the chips are down. Organizational behavior and human performance, 31(2), 194-202.

Jackson, J. (2019). Happy partisans and extreme political views: The impact of national versus local representation on well-being. European Journal of Political Economy, 58, 192-202.

James, Jr, H. S. (2011). Is the just man a happy man? An empirical study of the relationship between ethics and subjective well-being. Kyklos, 64(2), 193-212.

Kahyaoğlu, M. B., \& Ican, Ö. (2017). Risk aversion and emotions in DoND. International Journal of Economics and Finance, 9(1), 32-46.

Koch, C. (2013). The virtue ethics hypothesis: Is there a nexus between virtues and well-being? Technical report, Verein fur Socialpolitik / German Economic Association.

Konow, J. (2010). Mixed feelings: Theories of and evidence on giving. Journal of Public Economics, 94(3-4), 279-297.

Lane, T. (2017). How does happiness relate to economic behaviour? A review of the literature. Journal of Behavioral and Experimental Economics, 68, 62-78.

MacKerron, G. (2012). Happiness economics from 35000 feet. Journal of Economic Surveys, 26(4), 705-735.

Mill, J. (1991). On Liberty and Other Essays. Oxford University Press, Oxford. Olson, M. (1965). The Logic of Collective Action. Public Goods and the Theory of Groups. Harvard University Press, Cambridge (Mass.).

Oreopoulos, P., \& Salvanes, K. G. (2011). Priceless: The nonpecuniary benefits of schooling. Journal of Economic Perspectives, 25(1), 159-84.

Putnam, R. (1993). Making Democracy Work: Civic Traditions in Modern Italy. Princeton University Press, Princeton (NJ).

Shields, M. A., Price, S. W., \& Wooden, M. (2009). Life satisfaction and the economic and social characteristics of neighbourhoods. Journal of Population Economics, 22(2), 421443.

Stavrova, O., Schlösser, T., \& Fetchenhauer, D. (2013). Are virtuous people happy all around the world? Civic virtue, antisocial punishment, and subjective well-being across cultures. Personality and Social Psychology Bulletin, 39(7), 927-942.

Stevenson, B., \& Wolfers, J. (2009). The paradox of declining female happiness. American Economic Journal: Economic Policy, 1(2), 190-225.

Veenhoven, R. (2010). Capability and happiness: Conceptual difference and reality links. The Journal of Socio-Economics, 39(3), 344-350.

Yechiam, E., Telpaz, A., Krupenia, S., \& Rafaeli, A. (2016). Unhappiness intensifies the avoidance of frequent losses while happiness overcomes it. Frontiers in psychology, 7 , 1703. 
Table 1. Summary statistics

Data are from SHIW 2004, household heads born in odd years. The table reports means and standard deviations for the main variables used in the paper. Income and wealth are in thousand euros. The sample size is 3798 .

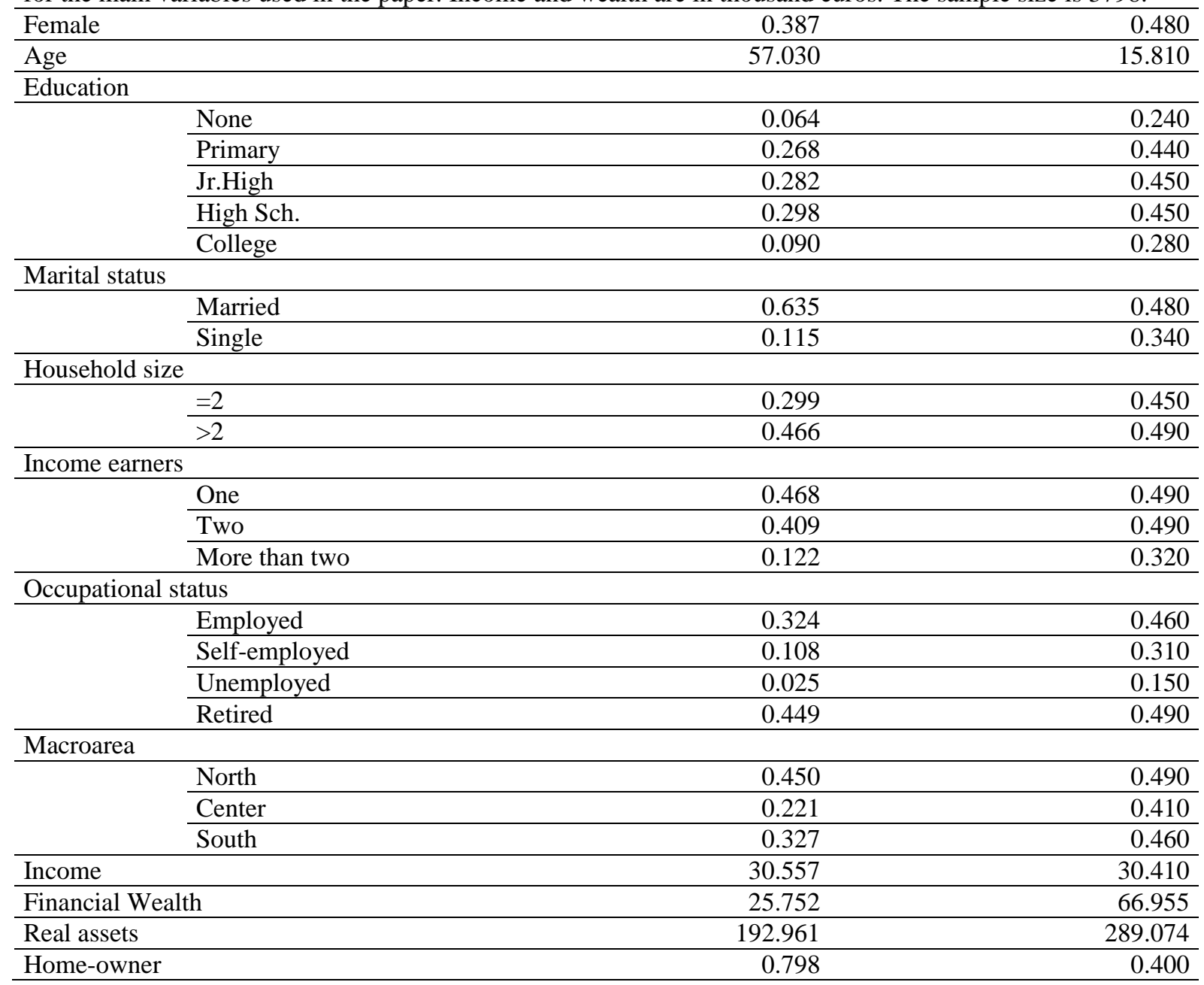


Table 2. Determinants of civic virtue

Data are from SHIW 2004, the sample size is 3532, house- hold heads born in odd years. Dependent variable:

Civicness. Estimates from Ordered Probit models. Standard errors in parenthesis

\begin{tabular}{|c|c|c|c|}
\hline & Ticket & Wallet & Car \\
\hline Age & $\begin{array}{c}-0.014 \\
(0.009)\end{array}$ & $\begin{array}{l}-0.006 \\
(0.009)\end{array}$ & $\begin{array}{c}-0.01 \\
(0.009)\end{array}$ \\
\hline Age & $\begin{array}{c}0.004 \\
(0.008) \\
\end{array}$ & $\begin{array}{c}-0.002 \\
(0.008)\end{array}$ & $\begin{array}{c}0.002 \\
(0.008)\end{array}$ \\
\hline Female & $\begin{array}{c}0.015 \\
(0.045)\end{array}$ & $\begin{array}{l}-0.091 \\
(0.046)\end{array}$ & $\begin{array}{c}-0.029 \\
(0.046)\end{array}$ \\
\hline Married & $\begin{array}{c}0.11 \\
(0.069)\end{array}$ & $\begin{array}{c}0.087 \\
(0.071)\end{array}$ & $\begin{array}{c}0.229 \\
(0.073)\end{array}$ \\
\hline Single & $\begin{array}{c}0.068 \\
(0.078)\end{array}$ & $\begin{array}{c}0.001 \\
(0.080)\end{array}$ & $\begin{array}{c}0.151 \\
(0.080)\end{array}$ \\
\hline Junior High School & $\begin{array}{c}-0.15 \\
(0.055)\end{array}$ & $\begin{array}{c}-0.158 \\
(0.057)\end{array}$ & $\begin{array}{l}-0.204 \\
(0.058)\end{array}$ \\
\hline High School & $\begin{array}{c}-0.209 \\
(0.063)\end{array}$ & $\begin{array}{c}-0.184 \\
(0.064)\end{array}$ & $\begin{array}{l}-0.221 \\
(0.065)\end{array}$ \\
\hline College & $\begin{array}{l}-0.436 \\
(0.090)\end{array}$ & $\begin{array}{l}-0.425 \\
(0.094)\end{array}$ & $\begin{array}{c}-0.348 \\
(0.089)\end{array}$ \\
\hline Unemployed & $\begin{array}{c}-0.163 \\
(0.141) \\
\end{array}$ & $\begin{array}{l}-0.281 \\
(0.146)\end{array}$ & $\begin{array}{c}-0.247 \\
(0.141)\end{array}$ \\
\hline Selfemployed & $\begin{array}{c}0.022 \\
(0.066) \\
\end{array}$ & $\begin{array}{c}-0.082 \\
(0.068)\end{array}$ & $\begin{array}{l}-0.053 \\
(0.067)\end{array}$ \\
\hline Retired & $\begin{array}{c}-0.046 \\
(0.066) \\
\end{array}$ & $\begin{array}{c}-0.072 \\
(0.067) \\
\end{array}$ & $\begin{array}{c}-0.071 \\
(0.067) \\
\end{array}$ \\
\hline Income earners $\geq 2$ & $\begin{array}{c}0.082 \\
(0.071) \\
\end{array}$ & $\begin{array}{c}0.127 \\
(0.073) \\
\end{array}$ & $\begin{array}{c}0.016 \\
(0.074) \\
\end{array}$ \\
\hline Household size $=2$ & $\begin{array}{c}0.019 \\
(0.072) \\
\end{array}$ & $\begin{array}{c}-0.047 \\
(0.074)\end{array}$ & $\begin{array}{c}-0.059 \\
(0.076)\end{array}$ \\
\hline Household size $>2$ & $\begin{array}{c}-0.077 \\
(0.086) \\
\end{array}$ & $\begin{array}{c}-0.132 \\
(0.089) \\
\end{array}$ & $\begin{array}{c}-0.15 \\
(0.089) \\
\end{array}$ \\
\hline Home owner & $\begin{array}{c}-0.204 \\
(0.069)\end{array}$ & $\begin{array}{c}-0.204 \\
(0.070)\end{array}$ & $\begin{array}{l}-0.185 \\
(0.071) \\
\end{array}$ \\
\hline Medium City & $\begin{array}{c}0.191 \\
(0.041)\end{array}$ & $\begin{array}{c}0.235 \\
(0.042)\end{array}$ & $\begin{array}{c}0.248 \\
(0.042)\end{array}$ \\
\hline Big City & $\begin{array}{c}0.147 \\
(0.073)\end{array}$ & $\begin{array}{c}0.253 \\
(0.071)\end{array}$ & $\begin{array}{c}0.259 \\
(0.072)\end{array}$ \\
\hline Center & $\begin{array}{c}0.138 \\
(0.050)\end{array}$ & $\begin{array}{c}0.174 \\
(0.052)\end{array}$ & $\begin{array}{c}0.103 \\
(0.054)\end{array}$ \\
\hline South & $\begin{array}{c}0.199 \\
(0.050) \\
\end{array}$ & $\begin{array}{c}0.252 \\
(0.051) \\
\end{array}$ & $\begin{array}{c}0.268 \\
(0.050) \\
\end{array}$ \\
\hline $\log$ (income) & $\begin{array}{c}-0.087 \\
(0.053)\end{array}$ & $\begin{array}{l}-0.153 \\
(0.050)\end{array}$ & $\begin{array}{c}-0.157 \\
(0.052)\end{array}$ \\
\hline $\log$ (fin wealth) & $\begin{array}{c}-0.048 \\
(0.014)\end{array}$ & $\begin{array}{l}-0.043 \\
(0.014)\end{array}$ & $\begin{array}{c}-0.042 \\
(0.014)\end{array}$ \\
\hline $\log ($ real assets $)$ & $\begin{array}{c}0.005 \\
(0.013)\end{array}$ & $\begin{array}{c}0.019 \\
(0.014)\end{array}$ & $\begin{array}{c}0.024 \\
(0.014)\end{array}$ \\
\hline
\end{tabular}


Table 3. Happiness and civic virtue

Data are from SHIW 2004, the sample size is 3532, household heads born in odd years. Dependent variable: Happiness. Estimates from Ordered Probit models. "Never" and "Always" stand for never justifiable and always justifi- able behavior, respectively. Standard errors in parenthesis.

\begin{tabular}{|c|c|c|c|c|}
\hline Ticket (never) & & $\begin{array}{c}0.174 \\
(0.035) \\
\end{array}$ & & \\
\hline Wallet (never) & & & $\begin{array}{c}0.119 \\
(0.035)\end{array}$ & \\
\hline Car (never) & & & & $\begin{array}{c}0.135 \\
(0.036)\end{array}$ \\
\hline Age & $\begin{array}{c}-0.046 \\
(0.008)\end{array}$ & $\begin{array}{c}-0.047 \\
(0.008)\end{array}$ & $\begin{array}{c}-0.046 \\
(0.008)\end{array}$ & $\begin{array}{c}-0.046 \\
(0.008)\end{array}$ \\
\hline Age & $\begin{array}{c}0.033 \\
(0.007)\end{array}$ & $\begin{array}{c}0.033 \\
(0.007)\end{array}$ & $\begin{array}{c}0.033 \\
(0.007)\end{array}$ & $\begin{array}{c}0.033 \\
(0.007)\end{array}$ \\
\hline Female & $\begin{array}{c}0.032 \\
(0.041)\end{array}$ & $\begin{array}{c}0.035 \\
(0.041)\end{array}$ & $\begin{array}{c}0.028 \\
(0.041)\end{array}$ & $\begin{array}{c}0.032 \\
(0.041)\end{array}$ \\
\hline Married & $\begin{array}{c}0.551 \\
(0.065)\end{array}$ & $\begin{array}{c}0.561 \\
(0.066)\end{array}$ & $\begin{array}{c}0.556 \\
(0.066)\end{array}$ & $\begin{array}{c}0.565 \\
(0.066)\end{array}$ \\
\hline Single & $\begin{array}{c}0.065 \\
(0.071) \\
\end{array}$ & $\begin{array}{c}0.069 \\
(0.070) \\
\end{array}$ & $\begin{array}{c}0.066 \\
(0.070) \\
\end{array}$ & $\begin{array}{c}0.073 \\
(0.070) \\
\end{array}$ \\
\hline Junior High School & $\begin{array}{c}0.147 \\
(0.053)\end{array}$ & $\begin{array}{c}0.138 \\
(0.053)\end{array}$ & $\begin{array}{c}0.140 \\
(0.053)\end{array}$ & $\begin{array}{c}0.137 \\
(0.053)\end{array}$ \\
\hline High School & $\begin{array}{c}0.285 \\
(0.055)\end{array}$ & $\begin{array}{c}0.268 \\
(0.056)\end{array}$ & $\begin{array}{c}0.275 \\
(0.055)\end{array}$ & $\begin{array}{c}0.272 \\
(0.055)\end{array}$ \\
\hline College & $\begin{array}{c}0.239 \\
(0.076)\end{array}$ & $\begin{array}{c}0.211 \\
(0.076)\end{array}$ & $\begin{array}{c}0.219 \\
(0.076)\end{array}$ & $\begin{array}{c}0.224 \\
(0.076)\end{array}$ \\
\hline Unemployed & $\begin{array}{c}-0.355 \\
(0.135)\end{array}$ & $\begin{array}{c}-0.369 \\
(0.135)\end{array}$ & $\begin{array}{c}-0.372 \\
(0.135)\end{array}$ & $\begin{array}{c}-0.371 \\
(0.134)\end{array}$ \\
\hline Selfemployed & $\begin{array}{c}-0.065 \\
(0.058)\end{array}$ & $\begin{array}{c}-0.059 \\
(0.058)\end{array}$ & $\begin{array}{l}-0.067 \\
(0.058)\end{array}$ & $\begin{array}{c}-0.064 \\
(0.058)\end{array}$ \\
\hline Retired & $\begin{array}{c}0.003 \\
(0.058) \\
\end{array}$ & $\begin{array}{c}0.007 \\
(0.058) \\
\end{array}$ & $\begin{array}{c}0.001 \\
(0.058) \\
\end{array}$ & $\begin{array}{c}0.001 \\
(0.058) \\
\end{array}$ \\
\hline Income earners $\geq 2$ & $\begin{array}{c}0.015 \\
(0.061) \\
\end{array}$ & $\begin{array}{c}0.019 \\
(0.060) \\
\end{array}$ & $\begin{array}{c}0.019 \\
(0.061) \\
\end{array}$ & $\begin{array}{c}0.013 \\
(0.061) \\
\end{array}$ \\
\hline Household size $=2$ & $\begin{array}{c}0.026 \\
(0.066)\end{array}$ & $\begin{array}{c}0.027 \\
(0.066)\end{array}$ & $\begin{array}{c}0.025 \\
(0.066)\end{array}$ & $\begin{array}{c}0.022 \\
(0.066)\end{array}$ \\
\hline Household size $>2$ & $\begin{array}{c}-0.03 \\
(0.078)\end{array}$ & $\begin{array}{c}-0.033 \\
(0.078)\end{array}$ & $\begin{array}{c}-0.033 \\
(0.078)\end{array}$ & $\begin{array}{c}-0.036 \\
(0.078)\end{array}$ \\
\hline Homeowner & $\begin{array}{c}0.164 \\
(0.066)\end{array}$ & $\begin{array}{c}0.151 \\
(0.066)\end{array}$ & $\begin{array}{c}0.154 \\
(0.066)\end{array}$ & $\begin{array}{c}0.154 \\
(0.066)\end{array}$ \\
\hline Medium City & $\begin{array}{c}-0.089 \\
(0.038)\end{array}$ & $\begin{array}{c}-0.75 \\
(0.038)\end{array}$ & $\begin{array}{c}-0.78 \\
(0.038)\end{array}$ & $\begin{array}{c}0.77 \\
(0.038)\end{array}$ \\
\hline Big City & $\begin{array}{c}-0.109 \\
(0.061)\end{array}$ & $\begin{array}{c}-.102 \\
(0.061)\end{array}$ & $\begin{array}{c}-0.098 \\
(0.061)\end{array}$ & $\begin{array}{c}-0.098 \\
(0.061)\end{array}$ \\
\hline Center & $\begin{array}{c}-0.095 \\
(0.047)\end{array}$ & $\begin{array}{c}-0.087 \\
(0.047)\end{array}$ & $\begin{array}{l}-0.091 \\
(0.047)\end{array}$ & $\begin{array}{c}-0.095 \\
(0.047)\end{array}$ \\
\hline South & $\begin{array}{c}-0.200 \\
(0.045)\end{array}$ & $\begin{array}{c}-0.194 \\
(0.045)\end{array}$ & $\begin{array}{c}-0.194 \\
(0.045)\end{array}$ & $\begin{array}{c}-0.192 \\
(0.045)\end{array}$ \\
\hline $\log$ (income) & $\begin{array}{c}0.068 \\
(0.045)\end{array}$ & $\begin{array}{c}0.059 \\
(0.045)\end{array}$ & $\begin{array}{c}0.06 \\
(0.045)\end{array}$ & $\begin{array}{c}0.06 \\
(0.045)\end{array}$ \\
\hline $\log$ (fin wealth) & $\begin{array}{c}0.033 \\
(0.014)\end{array}$ & $\begin{array}{c}0.030 \\
(0.014)\end{array}$ & $\begin{array}{c}0.031 \\
(0.014)\end{array}$ & $\begin{array}{c}0.030 \\
(0.014)\end{array}$ \\
\hline $\log$ (real assets) & $\begin{array}{c}0.022 \\
(0.013)\end{array}$ & $\begin{array}{c}0.022 \\
(0.013)\end{array}$ & $\begin{array}{c}0.023 \\
(0.013)\end{array}$ & $\begin{array}{c}0.023 \\
(0.013)\end{array}$ \\
\hline
\end{tabular}


Table 4. Happiness, civic virtue and selfishness

Data are from SHIW 2004, the sample size is 3532, household heads born in odd years. Dependent variable: Happiness. Estimates from Ordered Probit models. "Never" and "Always" stand for never justifiable and always justifi- able behavior, respectively. Standard errors in parenthesis.

\begin{tabular}{|c|c|c|c|}
\hline Ticket (Never) & $\begin{array}{c}0.189 \\
(0.036) \\
\end{array}$ & & \\
\hline Ticket (always) & $\begin{array}{c}0.577 \\
(0.210)\end{array}$ & & \\
\hline Wallet (never) & & $\begin{array}{c}0.13 \\
(0.035) \\
\end{array}$ & \\
\hline Wallet (always) & & $\begin{array}{c}0.485 \\
(0.234) \\
\end{array}$ & \\
\hline Car (never) & & & $\begin{array}{c}0.153 \\
(0.036)\end{array}$ \\
\hline Car (always) & & & $\begin{array}{c}0.725 \\
(0.205) \\
\end{array}$ \\
\hline Age & $\begin{array}{c}-0.046 \\
(0.008) \\
\end{array}$ & $\begin{array}{c}-0.046 \\
(0.008) \\
\end{array}$ & $\begin{array}{l}-0.046 \\
(0.008) \\
\end{array}$ \\
\hline Age & $\begin{array}{c}0.032 \\
(0.007)\end{array}$ & $\begin{array}{c}0.033 \\
(0.007)\end{array}$ & $\begin{array}{c}0.033 \\
(0.007) \\
\end{array}$ \\
\hline Female & $\begin{array}{c}0.036 \\
(0.041) \\
\end{array}$ & $\begin{array}{c}0.03 \\
(0.041) \\
\end{array}$ & $\begin{array}{c}0.036 \\
(0.041) \\
\end{array}$ \\
\hline Married & $\begin{array}{c}0.562 \\
(0.066)\end{array}$ & $\begin{array}{c}0.555 \\
(0.066)\end{array}$ & $\begin{array}{c}0.564 \\
(0.066)\end{array}$ \\
\hline Single & $\begin{array}{c}0.069 \\
(0.071) \\
\end{array}$ & $\begin{array}{c}0.067 \\
(0.071) \\
\end{array}$ & $\begin{array}{c}0.078 \\
(0.071) \\
\end{array}$ \\
\hline Junior High School & $\begin{array}{c}0.136 \\
(0.054) \\
\end{array}$ & $\begin{array}{c}0.14 \\
(0.053)\end{array}$ & $\begin{array}{c}0.141 \\
(0.054) \\
\end{array}$ \\
\hline High School & $\begin{array}{c}0.267 \\
(0.055)\end{array}$ & $\begin{array}{c}0.274 \\
(0.055)\end{array}$ & $\begin{array}{c}0.272 \\
(0.055) \\
\end{array}$ \\
\hline College & $\begin{array}{c}0.215 \\
(0.076) \\
\end{array}$ & $\begin{array}{c}0.221 \\
(0.076) \\
\end{array}$ & $\begin{array}{c}0.229 \\
(0.076) \\
\end{array}$ \\
\hline Unemployed & $\begin{array}{c}-0.378 \\
(0.135) \\
\end{array}$ & $\begin{array}{c}-0.382 \\
(0.134) \\
\end{array}$ & $\begin{array}{l}-0.384 \\
(0.133) \\
\end{array}$ \\
\hline Selfemployed & $\begin{array}{c}-0.059 \\
(0.057) \\
\end{array}$ & $\begin{array}{l}-0.064 \\
(0.058)\end{array}$ & $\begin{array}{l}-0.063 \\
(0.057) \\
\end{array}$ \\
\hline Retired & $\begin{array}{c}0.007 \\
(0.058) \\
\end{array}$ & $\begin{array}{c}0.001 \\
(0.058) \\
\end{array}$ & $\begin{array}{c}0.001 \\
(0.058) \\
\end{array}$ \\
\hline Income earners $\geq 2$ & $\begin{array}{c}0.018 \\
(0.061)\end{array}$ & $\begin{array}{c}0.018 \\
(0.061)\end{array}$ & $\begin{array}{c}0.008 \\
(0.061)\end{array}$ \\
\hline Household size $=2$ & $\begin{array}{c}0.031 \\
(0.066) \\
\end{array}$ & $\begin{array}{c}0.031 \\
(0.066) \\
\end{array}$ & $\begin{array}{c}0.028 \\
(0.066) \\
\end{array}$ \\
\hline Household size $>2$ & $\begin{array}{c}-0.023 \\
(0.078) \\
\end{array}$ & $\begin{array}{l}-0.024 \\
(0.078)\end{array}$ & $\begin{array}{l}-0.022 \\
(0.077) \\
\end{array}$ \\
\hline Homeowner & $\begin{array}{c}0.156 \\
(0.066)\end{array}$ & $\begin{array}{c}0.156 \\
(0.067)\end{array}$ & $\begin{array}{c}0.158 \\
(0.066)\end{array}$ \\
\hline Medium City & $\begin{array}{l}-0.075 \\
(0.038) \\
\end{array}$ & $\begin{array}{l}-0.078 \\
(0.038) \\
\end{array}$ & $\begin{array}{l}-0.082 \\
(0.038) \\
\end{array}$ \\
\hline Big City & $\begin{array}{c}-0.103 \\
(0.061) \\
\end{array}$ & $\begin{array}{c}-0.098 \\
(0.061) \\
\end{array}$ & $\begin{array}{l}-0.099 \\
(0.061) \\
\end{array}$ \\
\hline Center & $\begin{array}{c}-0.088 \\
(0.047)\end{array}$ & $\begin{array}{l}-0.091 \\
(0.047)\end{array}$ & $\begin{array}{l}-0.098 \\
(0.047)\end{array}$ \\
\hline South & $\begin{array}{l}-0.199 \\
(0.045)\end{array}$ & $\begin{array}{l}-0.198 \\
(0.045)\end{array}$ & $\begin{array}{l}-0.198 \\
(0.045)\end{array}$ \\
\hline$\overline{\log \text { (income) }}$ & $\begin{array}{c}0.051 \\
(0.045) \\
\end{array}$ & $\begin{array}{c}0.055 \\
(0.045) \\
\end{array}$ & $\begin{array}{c}0.059 \\
(0.045) \\
\end{array}$ \\
\hline $\log$ (fin wealth) & $\begin{array}{c}0.033 \\
(0.014) \\
\end{array}$ & $\begin{array}{c}0.031 \\
(0.014) \\
\end{array}$ & $\begin{array}{c}0.032 \\
(0.014) \\
\end{array}$ \\
\hline $\log$ (real assets) & $\begin{array}{c}0.021 \\
(0.013)\end{array}$ & $\begin{array}{c}0.022 \\
(0.013)\end{array}$ & $\begin{array}{c}0.02 \\
(0.013)\end{array}$ \\
\hline
\end{tabular}




\section{Table 5. Happiness and Civic Virtue- Robustness I}

Data are from SHIW 2004, the sample size is 3532, household heads born in odd years. Dependent variable: Happiness (Low happiness: Below me- dian; Median Happiness; High Happiness: above median). Estimates from Ordered Probit models. "Never" and "Always" stand for never justifiable and always justifiable behavior, respectively. Standard errors in parenthesis.

\begin{tabular}{lc}
\hline Ticket (never) & 0.237 \\
& $(0.041)$ \\
\hline Ticket (always) & 0.587 \\
& $(0.199)$
\end{tabular}

\begin{tabular}{|c|c|c|c|}
\hline Wallet (never) & & $\begin{array}{c}0.161 \\
(0.041)\end{array}$ & \\
\hline Wallet (always) & & $\begin{array}{c}0.449 \\
(0.225)\end{array}$ & \\
\hline Car (never) & & & $\begin{array}{c}0.156 \\
(0.042)\end{array}$ \\
\hline Car (always) & & & $\begin{array}{c}0.74 \\
(0.219)\end{array}$ \\
\hline $\log$ (income) & $\begin{array}{c}0.041 \\
(0.051)\end{array}$ & $\begin{array}{c}0.046 \\
(0.050)\end{array}$ & $\begin{array}{c}0.051 \\
(0.050)\end{array}$ \\
\hline $\log$ (fin wealth) & $\begin{array}{c}0.034 \\
(0.015)\end{array}$ & $\begin{array}{c}0.033 \\
(0.015)\end{array}$ & $\begin{array}{c}0.033 \\
(0.015)\end{array}$ \\
\hline $\log$ (real assets) & $\begin{array}{c}0.022 \\
(0.015)\end{array}$ & $\begin{array}{c}0.024 \\
(0.015)\end{array}$ & $\begin{array}{c}0.022 \\
(0.015)\end{array}$ \\
\hline Regional Dummies & Yes & Yes & Yes \\
\hline City Dummies & Yes & Yes & Yes \\
\hline Demographic controls & Yes & Yes & Yes \\
\hline
\end{tabular}

\section{Table 6. Happiness and Civic Virtue- Robustness II}

Data are from SHIW 2004, the sample size is 3532, household heads born in odd years. Dependent variable: Happiness (Low happiness: Below me- dian; Median Happiness; High Happiness: above median). Estimates from Ordered Probit models. "Never" and "AlmostAlways" stand for never justifiable (score=1) and almost always justifiable (score>7) behavior, respectively. Standard errors in parenthesis.

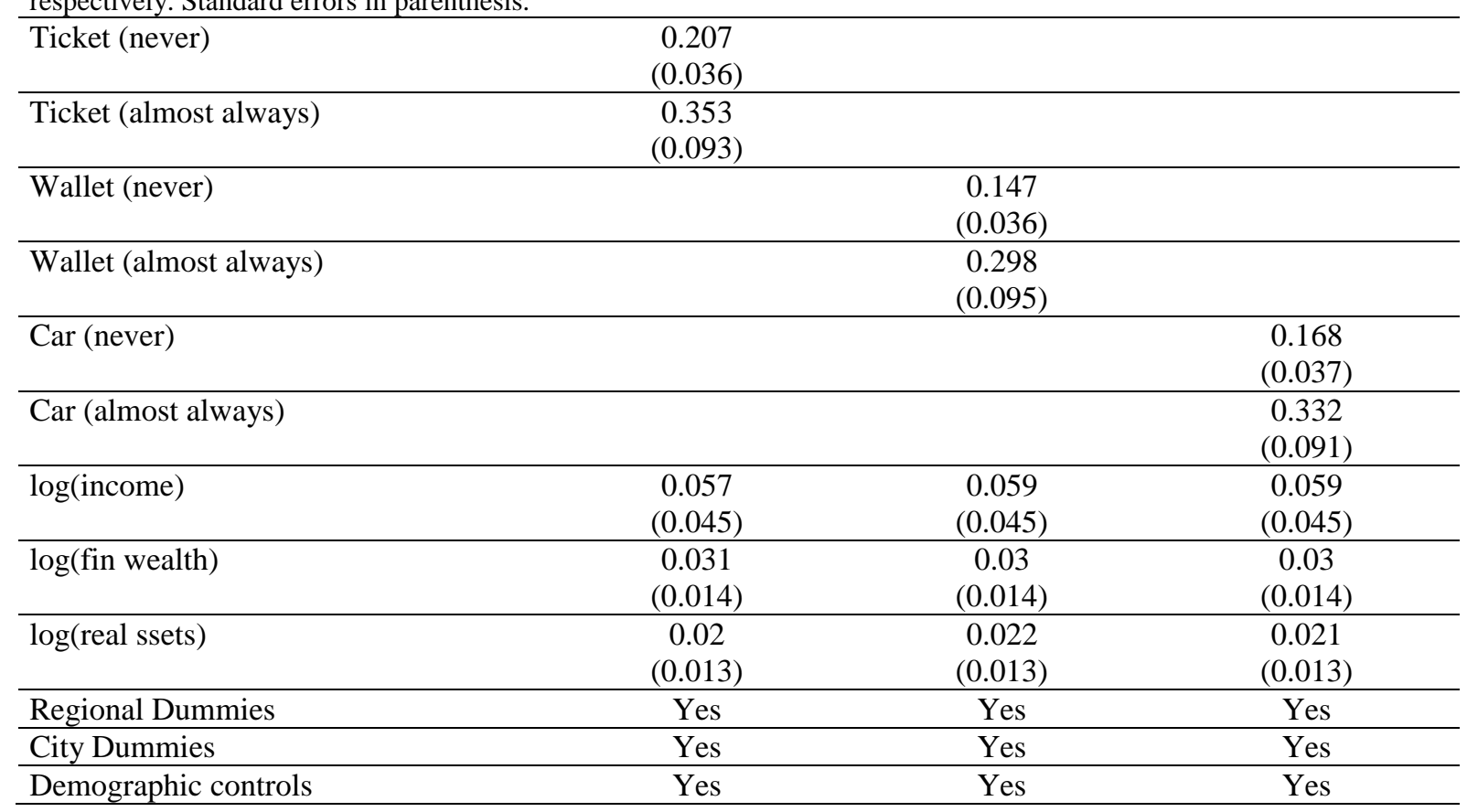


Table 7. Happiness and Civic Virtue- Robustness III

Data are from SHIW 2004, the sample size is 3532, household heads born in odd years. Dependent variable: Happiness. Civic if "never" justifiable to to three questions on Ticket, Wallet and Car; Selfish if "always" justifiable. Estimates from Ordered Probit models. "Never" and "Always" stand for never justifiable and always justifiable behavior, respectively. Standard errors in parenthesis.

\begin{tabular}{lc}
\hline Civic & 0.174 \\
& $(0.036)$ \\
\hline Selfish & 0.959 \\
& $(0.339)$ \\
\hline $\log ($ income $)$ & 0.049 \\
& $(0.045)$ \\
\hline $\log$ (fin wealth) & 0.032 \\
& $(0.014)$ \\
\hline $\log ($ real assets $)$ & 0.023 \\
& $(0.013)$ \\
\hline Regional Dummies & Yes \\
\hline City Dummies & Yes \\
\hline Demographic controls & Yes \\
\hline
\end{tabular}

